\title{
MAPPING OF POPULATION DIVERSITY IN CANADA AND GERMANY: DIFFERENT STRATEGIES, SIMILAR PRAGMATISM
}

\author{
Caroline Schultz ${ }^{1}$
}

\begin{abstract}
The aim of this paper is to compare the respective approaches of Canada and Germany in statistically mapping population diversity and to offer possible explanations for the differences and commonalities observed. In order to investigate this, the paper takes into account the concept of 'politics of belonging' as a theoretical background and considers the functions of national statistics in categorizing different groups of people. There are different strategies of mapping population diversity and, inter alia, two models can be distinguished: while some countries explicitly include questions on elusive concepts of 'origin' in their population data collection, others refrain from doing so and instead derive different subgroups from information on citizenship and place of birth. Taking Canada as an example of the first group of countries and Germany of the second, and delineating recent changes within their respective strategies of measuring diversity within their populations, this paper argues that Canada and Germany converge towards a new pragmatism in the approaches of measuring diversity in population statistics.
\end{abstract}

\footnotetext{
${ }^{1}$ Caroline Schultz is a research associate and doctoral candidate at the Chair of Political Sociology at the University of Bamberg and researcher at the Expert Council of German Foundations on Integration and Migration.
} 


\section{Introduction}

States have an interest in statistically mapping their population, historically for the purpose of unifying and creating homogeneity in ongoing processes of nation building, nowadays seemingly first and foremost in order to design policies and measure their outcomes. However, even today censuses do not only ask questions on date of birth or level of income, but also include sections related to a person's identity or 'origin'. There are several different state strategies to identify 'ethnic' subgroups within the population statistically. Two of the most common are 1) collecting data on concepts such as 'race', 'origin', 'ethnicity', or 'ancestry', relying on the selfidentification of the population; and 2) deriving a person's 'origins' from their own and their parents' place of birth or citizenship instead. Apart from these, there are several mixed approaches and some states do not collect data on ethnic or migrant origin at all, such as France (cf. Jacobs et al. 2009; Valente 2010; Simon 2012; see also SVR 2015, 142-153).

The objective of the paper is to understand why some states follow the strategy 1 and why others follow strategy 2 , as well as how these strategies have evolved over time. The hypothesis being studied is that there has been a shift from ideologically driven to more pragmatic practices of statistically mapping population diversity; and that this shift can be observed even across countries employing different strategies of measuring population diversity. Ideologically driven practices are understood here to be closely related to the respective idea or myth of nationhood, while pragmatic practices are defined as those that are based on considerations of what is deemed to be practical and instrumental in tracking the effects of (economic) integration measures (cf. Joppke 2007) in order to detect and enable counteraction of discrimination and inequalities in modern immigration societies. It is important to emphasize that this is not meant as an 'either-or'-comparison, but rather as a continuum. In principle, both strategies outlined above can be driven by a combination of both ideological as well as pragmatic elements. To clarify, consider the example of France which does not collect any data on ethnicity due to its republican strategy of indifference: its state philosophy is meant to be colour- and culture-blind (cf. e.g. Bertossi 2012; Whitol de Wenden, Salzbrunn and Weber 2013). The French approach of not collecting ethnic data is very close to the ideology end of the ideology-pragmatismcontinuum - it hazards the consequences of not being able to measure ethnic inequalities in society solely for the purpose of not moving away from its national myth of a colour-blind communauté des citoyens (Schnapper 1994; cf. also SVR 2015, 100).

The French approach, however, is not investigated further in this paper, as its strategy to statistically map diversity is a non-strategy at best. ${ }^{2}$ Rather, the paper uses the relatively unlike cases of Canada and Germany as two case studies for its comparative design of a 'most different' approach (cf. Bloemraad 2013). While Canada is following strategy 1 outlined above, trying to get hold of elusive concepts of 'origin', Germany is following strategy 2, using hard facts to determine a person's origin and assigning it from above.

The paper is structured as follows: In the first section, the literature of comparative migration study research on statistical mapping of diversity in Canada and Germany is briefly reviewed. Canada and Germany are then briefly introduced as countries traditionally known in migration

\footnotetext{
${ }^{2}$ France did take a step towards quantifying diversity in its population in 1999 with the introduction of the category 'immigrant' in its census. It still refrains from distinguishing between ethnic groups, however (Engler 2012; Jacobs et al. 2009).
} 
studies for adopting opposite approaches to nationhood, immigration, citizenship, and immigrant integration. In the next section, a theoretical background is provided using the concept of 'politics of belonging' and considering the functions of national statistics in categorizing various groups of people within society. From there, the two countries' current approach of labelling and counting immigrants and people with a (family) history of migration is contrasted against their respective history of nation building and immigration. In conclusion, the paper sums up the main points of the discussion and outlines questions for further study. ${ }^{3}$

\section{Literature review: comparative studies on state approaches to map diversity}

Census politics in countries of immigration have been studied only relatively recently. Three recent comparative works that cover at least one of the selected case studies (Canada and Germany) are of particular importance for this paper:

Thompson (2012) compares the census politics of the United States, the United Kingdom and Canada, focusing on the parallel emergence of mixed race categories. She argues that a combination of internal and external factors led to the meltdown of fixed one-race categories, including "demographic trends, increasingly unsettled perceptions about discrete racial categories, and a transnational norm surrounding the primacy of racial self-identification in census-taking" and calls this process across English-speaking countries of immigration a "normative shift towards multiracial multiculturalism" (Thompson 2012, 1421).

Stevens, Ishizawa and Grbic (2015) compare Canada's approach to measuring race and ethnicity in the census with those of two other big English-speaking settler-states, Australia and the United States, respectively. They find "important similarities in how these three nations define and describe subgroups with immigrant origins" (Stevens, Ishizawa and Grbic 2015, 14) and argue that these similarities are due to the similar challenges those states faced when gathering data on the 'ethnic' origins of their populations. These parallel problems include: first, the ambiguity and conflation of the concepts of 'race' and 'ethnicity'; second, the complexities that come up with intermarriage and the social trend of emphasizing 'identity' rather than biological features; and third, the respective behaviour of the population, i.e. the refusal to go with specific categories.

Both Thompson (2012) and Stevens, Ishizawa and Grbic (2015) hence focus on countries who apply strategy 1: explicitly collecting ethnic statistics. Simon (2012) uses a broader sample and reviews ethnic data collection in no less than 41 European countries. He argues that much is in flow in Europe as many countries that were previously reluctant to collect statistics on 'ethnicity' are now obliged to do so because of EU non-discrimination policies, and anticipates a "move from colour-blindness to "ethnic consciousness"" (Simon 2012, 1367). He finds that more than half (22) of the countries observed collect 'ethnic data', while almost all collect country of birth and citizenship. Of those 19 countries that do not collect data on ethnicity, six (mostly northern European countries) ask about the parents' place of birth. Two explanations are given for "this relative absence of statistical data on race and ethnicity in continental Europe" (Simon 2012, 1376). First, data protection laws in these countries define such data as 'sensitive' and hence prohibit collecting them; second, "these sensitive data are also perceived as inaccurate categories

\footnotetext{
${ }^{3}$ There are obvious limitations to this brief essay. It is not based on any systematic analysis of government or media documents, but mainly draws on and consolidates the findings of previous studies on the two separate cases and develops its own argument based on these previous findings.
} 
for describing population and analysing social processes since they challenge the representation of ethnically homogeneous societies“ (Ibid, 1376). In other words, the historically prevalent image of 'the nation' seems to play a role in the choice of collecting 'ethnic data' or only data on citizenship and place of birth.

\section{Canada and Germany: antipodes in mapping population diversity}

Canada and Germany have long been known for adopting opposite approaches to nationhood, immigration, citizenship, and immigrant integration. Recently, however, several researchers have identified processes of convergence between the two countries in various realms of migration and integration policy. ${ }^{4}$ The respective 'politics of belonging' by way of the census politics in regard to measuring ethnicity or ethnic origin in Canada and Germany do not appear to have been studied previously in a comparative way. ${ }^{5}$

The Canadian and German contexts are rather different. On one side of the Atlantic, there is the settler country Canada that historically values ethno-cultural difference of various population groups. Accordingly, to depict its multifaceted members, collating ethnicity statistics has a century-long tradition in Canada and-with minor and major changes along-is still being practiced today. On the European side, there is Germany, the 'latecomer' in migration and integration management, its myth of the nation having been first defined by 'culture' (Kulturnation) then by biological descent: Throughout the 20th century, it was mainly blood relations that determined who 'belonged' to German society. Parents passed on German citizenship to children, to put it simply. Given the role that ethnicity statistics played in facilitating the Holocaust (Seltzer 1998), it is not surprising that collection of explicitly ethnic data is entirely unimaginable in post-war Germany. ${ }^{6}$ Nonetheless, the eventual acknowledgement that Germany is a country of immigration and the related concerns of how to track social inequalities and discrimination, led to the introduction of the statistical category of 'migration background' in 2005. 'Migration background' is defined by the country of birth of oneself or one's parents.

\section{The politics of belonging and categorization in immigrant-receiving societies}

To understand that state strategies of mapping population diversity are embedded in wider attempts of fostering 'national identity' and are therefore originally ideological, it is fruitful to look into theoretical literature exploring what has been termed 'the politics of belonging'.

"We are who we are by virtue of who we are not" - This diagnosis by Aristide Zolberg (1999, 85) aptly pins down the processes of collective identity-making that inevitably occur in any agglomeration of people. Essentially, these are processes of boundary making, of defining oneself (or one's group) against a homogenized imagined 'other' (or several 'others'). From a state-centred perspective, these processes have been termed the 'politics of belonging' (or

\footnotetext{
${ }^{4}$ See for instance Triadafilopoulos 2012; Kolb 2014; Soennecken 2014.

${ }^{5}$ Bauder (2014) contrasts Canada's and Germany’s “immigration debates related to national belonging”, without taking into consideration the respective census politics.

${ }^{6}$ However, there were and continue to be privileged entrance rules for migration based on German ethnicity ('Volkszugehörigkeit') (cf. for instance Joppke 2005).
} 
sometimes 'politics of identity'), albeit the term is mostly only vaguely defined, if at all. According to Brubaker, politics of belonging are bound to exist because of an architectural flaw in the concept of the liberal nation-state, which is "conceptualized in both socio-scientific analysis and policy practice as an internally homogeneous, externally bounded political, legal, social, cultural, and (sometimes) economic space." (2010, 63). However in practice, states do not conform to this model. An exact congruence has never existed between the frontiers of the state and those of 'the nation' as an "imagined community" (Anderson 1991). Migration is one of the most obvious reasons for this idealized concept of the homogenous nation-state to remain just that - a concept. In fact, there is room to argue that "[ $\mathrm{t}]$ he state has historically used immigration policy as a tool in fostering a particular national identity" (Adamson, Triadafilopoulos and Zolberg 2011, 847).

Tracing the politics of belonging in countries of immigration is insightful as they influence opportunities for people within a society to take part in various parts of social life (cf. Crowley 1999). Membership of a 'nation' is not only determined by formal citizenship, but is managed by "ordinary people in the course of everyday life, using tacit understandings of who belongs and who does not, of us and them" (Brubaker 2010, 65). Winter (2014) takes the dichotomous model of 'us' versus 'them' one step further, explaining how the existence of outsiders, 'them', conditions the confrontations between 'us' and 'others' in "changing sets of triangular social relations", within a society made up of different groups that are unequal in terms of power (2014, 129). Although a lot of different societal forces are at play in the politics of belonging, choosing the state as the primary level of analysis when studying these processes is a relatively straightforward approach. This is because the state is the final entity to decide upon which categories to use in bureaucracy and population statistics. Obviously, it is impossible to completely disentangle other actors, precisely because the politics of membership, identity and belonging are social processes in which the public, the political and the media debate influence each other (cf. Pries 2013).

The politics of belonging overlap with, but are not synonymous to what has been termed "membership politics" for instance by Triadafilopoulos (2012) in his comparison of Canada's and Germany's "membership regimes" throughout the $20^{\text {th }}$ century. While membership politics determine who is allowed to migrate to a country (via immigration law and politics), and who is allowed to become a political member of that country (via citizenship politics) and under what conditions, it is harder to pin down the ways that politics of belonging work: the concept is arguably somewhat vague. It plays out visibly, though, in the categories and labels used for demarcating the 'us' from the 'other'.

Some basics about the function of categories and population statistics need to be stated: First of all, it is clear that on any level of discussion, be it political, societal, or academic, there is a necessity to name the entity in question (person, group, phenomenon), which is to be studied or whose plight one seeks to discuss. Categorizing is inevitable in academic research and policymaking; besides, this is how the human brain works in general: it puts things and people into imaginative boxes, i.e. categorizes in order to make sense of the world we live in. It is clear therefore that there is no alternative - for the policy-maker or for the researcher - to naming and labelling. In order for evidence-based policy-making to succeed, we need to know what works and why. However, at the same time that one acknowledges the inevitability of categories, one needs to acknowledge that it is imperative to discuss and at times question them, because "terminology is anything but irrelevant" (Düvell 2008, 484). Each label invokes certain 
connotations and tacitly reinforces power structures. ${ }^{7}$ One has to be aware that the labels put on people, and the boxes the state, the majority group - or themselves - stick them into, are socially constructed and by no means fixed. After all, boundary-making by the dominant group between minority groups ('them' and 'others') is clearly marked by, and a product of power relations within society (Winter 2011).

So what purpose does the collection of migration-related population data serve? It undoubtedly plays a vital part in re-creating and re-inventing the national identity of allegedly homogenous nation-states, and in this sense, it is inherently ideological. In other words, on the ideologypragmatism continuum introduced above, ethnic data collection leans originally very much on the ideology-side. As Simon (2012, 1376, emphasis added) explains, "[c]ensuses were implemented in most western European countries as equipment for nation building during the nineteenth century, and the political objective during this process of the 'invention of the Nation' was to create homogeneity against internal diversity by using unifying categories." 8 It is important to bear this historical background of census politics in mind, as it points to the principal dilemma faced by decision-makers of countries of immigration today. Collecting data on 'differences' (be they ethnic, racial, cultural or migration-related in more subtle ways) is a practical necessity in order to measure and track social inequalities and discrimination in superdiverse societies - the pragmatic element of ethnic data collection. However at the same time, precisely these categorizations might reify existing social boundaries or even create new ones. There is no way to escape the paradoxical situation that "[f]or detecting unequal opportunities or discrimination, instruments of measurement are needed, but at the moment of generating new categories, these turn out and get alive as forces of naming and blaming in public discourses and in the politics of ascription" (Pries 2013, 78). Therefore, a pragmatic approach to this dilemma engages in the statistical mapping of diversity with the purpose of maintaining social cohesion in diverse societies.

A brief disclaimer seems to be in order at this point. This paper is less focused on what would be the normatively 'right' way of approaching this dilemma. Instead, it seeks to understand and delineate the different paths of Canada and Germany in migration-paradigm or diversityparadigm statistical data collection. It finds that both experienced a shift away from an ideological towards a more pragmatic approach, while at the same time remaining fundamentally different in their respective strategies of mapping population diversity.

\footnotetext{
${ }^{7}$ For instance, Zhang $(2001,29 f)$ highlights the role that allegedly objective and scientific censuses have played in reifying the marginalization of the 'floating population' in China, claiming that "a census does not simply describe existing social groups; it reflects the state's vision for the ordering of a society."

${ }^{8}$ When the term 'nation-building' - which is often vaguely defined or used to describe a plethora of phenomena - is used in this paper, it is employed in the sense that von Bogdandy et al. $(2005,586)$ capture in their definition: "Nation-building is the most common form of a process of collective identity formation with a view to legitimizing public power within a given territory. This is an essentially indigenous process which often not only projects a meaningful future but also draws on existing traditions, institutions, and customs, redefining them as national characteristics in order to support the nation's claim to sovereignty and uniqueness. A successful nation-building process produces a cultural projection of the nation containing a certain set of assumptions, values and beliefs which can function as the legitimizing foundation of a state structure."
} 


\section{Case Studies}

\section{Canada: mapping origins and 'visible minorities' in the multicultural country}

In a report entitled "Immigration and Ethnocultural Diversity in Canada", Statistics Canada $(2013,6)$ explains: "Canada is a multicultural society whose ethnocultural make-up has been shaped over time by immigrants and their descendants. Each new wave of immigration has added to the nation's ethnic and cultural composition." In the 2011 National Household Survey, more than 200 different 'ethnic origins' were reported, 13 of which were declared by more than one million respondents, respectively. More than six million people were classified as belonging to a 'visible minority', representing about 19 percent of the population - the three largest of these groups are 'South Asians', 'Chinese', and 'Black'. About one third of those who reported to be anything other than 'white' - hence being categorized as a member of a 'visible minority' - were born in Canada (Statistics Canada 2013). ${ }^{9}$

To understand the vocabulary used by the statistics office, one has to take a brief look at the historical context within which Canada's politics of belonging have developed. Clearly, for Canada, "immigration is an integral part of national identity" (Bauder 2014, 9). The settler state has been described as a "multination state"; but it has to be remembered that "[t]he original incorporation of the Quebecois and Aboriginal communities into the Canadian political community was involuntary", as the communitarian Will Kymlicka $(1995,12)$ states in his influential book Multicultural Citizenship. In fact, as Kymlicka goes on to explain, "[m]any of the pivotal moments in Canadian history have centred on [...] attempts to renegotiate the terms of federation between English, French, and Aboriginals (1995, 12-13)." 10 Throughout the imagined history of Canada as home to nations of settlers, however, Indigenous peoples have been marginalized as 'the other', as they "challenge the cherished image of Canada as a country of immigrants who came in search for a better future" (Bauder 2014, 17).

Like other liberal democratic countries of immigration (Joppke 2005), Canada had been following an ethnic immigration policy and an assimilation-oriented integration model for the larger part of the 20 $0^{\text {th }}$ century (Kymlicka 1995; Triadafilopoulos 2012). Criteria based on race and geographical origin was used in Canadian selection procedures until 1967 (Bauder 2014). In 1971, multiculturalism was adopted as an official state policy, and later put into law in 1988 (Bauder 2014). ${ }^{11}$ A lot of research has been conducted on Canadian multiculturalism (for instance Kymlicka 2012; Winter 2015), but for the purpose of this paper it suffices to emphasize that while across western migrant-receiving countries, multiculturalism as a political approach to immigrant incorporation has come under assault in the last couple of years, it is still alive and striving in Canada. However, there seems to be evidence that "even in Canada multiculturalism

\footnotetext{
${ }^{9}$ See Question 19 of the 2011 National Household Survey, available from http://www23.statcan.gc.ca/imdbbmdi/instrument/5178_Q1_V1-eng.pdf (accessed 15.12.2016) and the respective Guide, available from https://www12.statcan.gc.ca/NHS-ENM/2011/ref/pdf/N1_guide_short_court.pdf (accessed 15.12.2016).

${ }^{10}$ Kymlicka (1995) draws a clear distinction between national minorities (with occupied territories within the state) and immigrant groups.

${ }^{11}$ Multiculturalism as a policy was often believed to be an extension of English-French dualism: "Commentators [...] tended to argue that the historical compromises reached to accommodate Quebec's cultural and linguistic difference have helped to prepare the rest of Canada to deal with the challenges of newer sources of ethnocultural diversity" (Winter 2014, 138). However, this changed in the early 1990s, because "[i]n the years leading up to the second Quebec referendum on independence in 1995, Québécois nationalist separatism [...] became increasingly regarded as the enfant terrible of Canadian multiculturalism" (Winter 2014, 138).
} 
has lost much of its original meaning" (Winter 2015, 1): while it used to refer to the recognition of group rights to maintain different cultural beliefs and traditions, in the 1990s the focus shifted to guaranteeing individual rights to difference.

While census politics have predated the politics of multiculturalism by far, it is likely that politics of multiculturalism have had an impact on shifts in census politics. It is against this backdrop of the multiculturalism as a national ethos that statistical mapping of diversity in Canadian censuses today has to be viewed. Canada belongs to a number of 'classic' immigration countries that have a long tradition of mapping their population's 'race' or origins. In Canada, these attempts go back as far as 1767 (Stevens, Ishizawa and Grbic 2015; cf. also Thompson 2012) - while the US collected information on 'race' for the first time in 1790 (Stevens, Ishizawa and Grbic 2015, 15). As in other countries all over the world, the Second World War and the experience of Nazi-Germany's inhuman racist ideology marked a turning point in the understanding and conception of 'race'. In two statements in 1950 and 1951, UNESCO recommended the concept of 'race' be dropped as a scientific fallacy, which illustrates this international paradigm shift (cf. Simon 2012, 1376-1377). Hence, in the 1951 census, Canada did not include explicit questions about 'race' any more, but instead took up questions about 'origins'. ${ }^{12}$ Implicitly, however, the concept remained (and still remains today) focused on biological ancestry, with respondents being asked to indicate the "ethnic or cultural group that the person or his or her male ancestor belonged to at the time of arrival on the North American continent" (Stevens, Ishizawa and Grbic 2015, 17). ${ }^{13}$

Table 1 shows how the question on 'origin' in the Canadian censuses evolved from 1951 to 2011. The concept of 'origin' was continuously modified, which according to Thompson $(2012,1409)$ can be attributed to three key factors, namely "demographic trends, increasingly unsettled perceptions about discrete racial categories, and a transnational norm surrounding the primacy of racial self-identification in census-taking". Thompson (2012) argues for the existence of the latter as not only Canada, but also the US and the UK switched from external ascription of ethnic/racial belonging to the concept of self-identification. However, note that self-identification statistics as a form of data production remain socially constructed to a considerable extent. This is shown for instance by the fact that bureaucrats subsume self-reported ethnic origins under the label of 'visible minorities', which is not explicitly mentioned in the NHS Questionnaire (2011) itself, but in later interpretation of the data (cf. Statistics Canada 2013).

\footnotetext{
${ }^{12}$ About the Canadian census: "The Canadian Census is conducted every five years across the country since 1956. Prior to 1951, it was conducted every 10 years. In 1971, with the exception of Indian reserves and remote areas, selfenumeration was first introduced where census representatives were dropping off questionnaires at every private dwelling and collecting them back soon after. Starting in 1991, all respondents in self-enumeration areas (over 98\% of the population) were asked to return their completed census forms by mail. In the 2006 Census, forms were delivered by Canada Post to about $70 \%$ of households. The remaining 30\% received the form from a census representative as in previous censuses. In the 2011 Census, 54\% of Canadian households completed their census form on-line" (Hamel and Béland 2013).

${ }^{13}$ The social importance of the question of one's 'origin' or ancestry is illustrated in the popularity of genealogy in Francophone Canada: Leroux $(2014,720)$ explains that owing to efforts by scholars and tens of thousands of interested laymen, "French Canadians can now trace their lineage back [...] to common founding male colonists in the seventeenth century [...] Genealogy, then, is not simply a search for one's ancestors; it also constructs the boundaries of the national family."
} 
Table 1: The question on 'origin' in the Canadian censuses, 1951-2011

\begin{tabular}{|c|c|c|c|}
\hline $\begin{array}{l}\text { Census } \\
\text { year }\end{array}$ & Concept & Mode & Options / examples \\
\hline 1951 & 'Origin' & Checkbox & $\begin{array}{l}\text { English, French, Irish, Netherlands, Scottish, } \\
\text { Norwegian, Welsh \& Manx, Polish, Czech \& Slovak, } \\
\text { Russian, Finnish, Swedish, German, Ukrainian, } \\
\text { Italian, Native Indian, Jewish, Unknown, If not listed } \\
\text { write below }\end{array}$ \\
\hline 1961 & $\begin{array}{l}\text { 'Ethnic } \\
\text { group' }\end{array}$ & Checkbox & $\begin{array}{l}\text { Austrian, Belgian, Czech, Danish, English, Estonian, } \\
\text { French, German, Greek, Icelandic, Irish, Italian, } \\
\text { Jewish, Lithuanian, Negro, Netherlands, Norwegian, } \\
\text { polish, Roumanian, Russian, Scottish, Slovak, } \\
\text { Swedish, Ukrainian, Welsh, Yugoslavic, Native } \\
\text { Indian - Band member /Non-Band, If not listed write } \\
\text { below }\end{array}$ \\
\hline 1971 & $\begin{array}{l}\text { 'Ethnic } \\
\text { group' }\end{array}$ & Checkbox & $\begin{array}{l}\text { English, French, German, Irish, Italian, Jewish, } \\
\text { Native Indian - Band, Native Indian - Non-Band, } \\
\text { Netherlands, Norwegian, Polish, Scottish, Ukrainian, } \\
\text { Other - write here }\end{array}$ \\
\hline 1981 & $\begin{array}{l}\text { 'Ethnic } \\
\text { origins' }\end{array}$ & Checkbox & $\begin{array}{l}\text { French, English, Irish, Scottish, German, Italian, } \\
\text { Ukrainian, Dutch, Polish, Jewish, Chinese, Native } \\
\text { Peoples (Inuit, Status or registered Indian, Non-status } \\
\text { Indian, Métis), Other }\end{array}$ \\
\hline 1986 & $\begin{array}{l}\text { 'Ethnic } \\
\text { group' }\end{array}$ & $\begin{array}{l}\text { Checkbox } \\
\text { plus write-in } \\
\text { ( } 3 \text { blank } \\
\text { lines) }\end{array}$ & $\begin{array}{l}\text { French, English, Irish, Scottish, German, Italian, } \\
\text { Ukrainian, Dutch (Neth.), Chinese, Jewish, Polish, } \\
\text { Black, Inuit, North Amer. Indian, Métis, Other ethnic } \\
\text { or cultural group(s) - (3 blank lines) }\end{array}$ \\
\hline 1991 & $\begin{array}{l}\text { 'Ethnic } \\
\text { group' }\end{array}$ & $\begin{array}{l}\text { Checkbox } \\
\text { plus } \\
\text { write-in } \\
\text { ( } 2 \text { blank } \\
\text { lines) }\end{array}$ & $\begin{array}{l}\text { French, English, German, Scottish, Italian, Irish, } \\
\text { Ukrainian, Chinese, Dutch, Jewish, Polish, Black, } \\
\text { North Amer. Indian, Métis, Inuit/Eskimo, Other } \\
\text { ethnic or cultural groups - Specify ( } 2 \text { blank lines) }\end{array}$ \\
\hline 1996 & Ethnic group' & $\begin{array}{l}\text { Write-in } \\
\text { ( } 4 \text { blank } \\
\text { lines) }\end{array}$ & $\begin{array}{l}\text { French, English, German, Scottish, Canadian, Italian, } \\
\text { Chinese, Cree, MicMac, Metis, Inuit (Eskimo), } \\
\text { Ukrainian, Dutch, East Indian, Polish, Portuguese, } \\
\text { Jewish, Haitian, Jamaican, Vietnamese, Lebanese, } \\
\text { Chilean, Somali, etc. }\end{array}$ \\
\hline 2001 & Ethnic group' & $\begin{array}{l}\text { Write-in } \\
(4 \text { blank } \\
\text { lines) }\end{array}$ & $\begin{array}{l}\text { Canadian, French, English, Chinese, Italian, German, } \\
\text { Scottish, Irish, Cree, MicMac, Metis, Inuit (Eskimo), } \\
\text { East Indian, Ukrainian, Dutch, Polish, Portuguese, } \\
\text { Filipino, Jewish, Greek, Vietnamese, Lebanese, }\end{array}$ \\
\hline
\end{tabular}




\begin{tabular}{|c|c|c|c|}
\hline & & & Chilean, Somali, etc. \\
\hline 2006 & Ethnic group' & $\begin{array}{l}\text { Write-in } \\
\text { ( } 4 \text { blank } \\
\text { lines) }\end{array}$ & $\begin{array}{l}\text { Canadian, English, French, Chinese, Italian, German, } \\
\text { Scottish, East Indian, Irish, Cree, Mi'kmaq } \\
\text { (MicMac), Métis, Inuit (Eskimo), Ukrainian, Dutch, } \\
\text { Filipino, Polish, Portuguese, Jewish, Greek, } \\
\text { Jamaican, Vietnamese, Lebanese, Chilean, } \\
\text { Salvadorean, Somali, etc. }\end{array}$ \\
\hline 2011 & $\begin{array}{l}\text { 'Ethnic } \\
\text { group' }\end{array}$ & $\begin{array}{l}\text { Write-in } \\
\text { ( } 4 \text { blank } \\
\text { lines) }\end{array}$ & $\begin{array}{l}\text { Canadian, English, French, Chinese, East Indian, } \\
\text { Italian, German, Scottish, Irish, Cree, Mi'kmaq, } \\
\text { Salish, Métis, Inuit, Filipino, Dutch, Ukrainian, } \\
\text { Polish, Portuguese, Greek, Korean, Vietnamese, } \\
\text { Jamaican, Jewish, Lebanese, Salvadorean, Somali, } \\
\text { Columbian, etc. }\end{array}$ \\
\hline
\end{tabular}

Source: Stevens, Ishizawa and Grbic 2015, own design

A decade after the establishment of the census, the question of 'origin' was re-named as 'ethnic group'-with the exception of the 1981 census. One of the main aspects in which this question was modified through the years was the number and type of options or examples available. Response categories included mostly categories named after European nations (e.g. 'Irish'), but also religious categories ('Jewish'), at times racial ones ('Negro' in 1961, 'Black' in 1986), and to various degrees and levels of detail categories for Indigenous peoples (e.g. 'Inuit'). While the selection of options had been arbitrary beforehand, in the 1980s it was decided that ethnic groups should be ordered according to the population counts of the previous survey year. Other institutional changes made in the 1980s (i.e. after the adoption of multiculturalism as the official political approach) included "self-enumeration, the acceptance of ambilineal ancestry, [...] and the acceptance - and later, the encouragement - of multiple responses" (Thompson 2012, 1420).

Conflation of the concepts of 'citizenship', 'nationality' and 'ethnicity' proved to be a serious problem for the statistics office, which tried to train its interviewers and later, when selfenumeration was used, the general public to understand its definition of 'origins'/'ethnic group': In 1991, it instructed respondents that "[e]thnic or cultural origin refers to the ethnic 'roots' or ancestral background of the population, and should not be confused with citizenship or nationality" (cited in Stevens, Ishizawa and Grbic 2015, 19).

Between 1991 and 1996, the answer mode changed from checkbox format to a write-in format, where examples on what to be put were listed below the question (cf. Table 1). As in the 1991 census, about 4 percent of respondents had written 'Canadian' into the blank lines, Statistics Canada had to include that as one of the examples provided in the 1996 census, according to its own previously set rules. This resulted in almost 20 percent reporting to be of 'Canadian' origin in 1996, and an additional 12 percent describing their 'ethnic group' as partially Canadian (for instance, Canadian-Ukrainian). Hence, in the words of Stevens, Ishizawa and Grbic, "the decades of Statistics Canada imploring the general population to distinguish between nationality and ethnic origins were undone in one fellow swoop" $(2015,28)$. This development also prompted Statistics Canada to introduce a new additional question on 'visible minority' in 1996 (Thompson 2012, 1420; Stevens, Ishizawa and Grbic 2015, 17). This new category was 
introduced in order to still be able to measure diversity in Canada, while about a third of the population now considers themselves to be 'Canadian' by ethnicity. Moreover, it shifted the responsibility for assigning an implicitly 'racial' category - the definition of 'visible minority' explicitly refers to 'race' - from the state to the respondents themselves (cf. Thompson 2012). Interestingly enough, the definition for 'visible minority' is included in the 1995 Employment Equality Act, which hints at one crucial motivation for measuring diversity in the first place: antidiscrimination politics.

The decision to allow more than one answer category to be marked was a pragmatic one, as Thompson argues:

In practical terms, because the implementation of the race question was controversial enough on its own, the state made attempts to minimize the potential criticisms that would undoubtedly arise if respondents were forced to choose only one racial affiliation while multiple responses to the ethnic question were encouraged. $(2012,1421)$

Canadian state officials chose a pragmatic approach in managing the politics of belonging that would fit with both historical contingencies of the imagined nation-state and international norms about changed concepts of 'race' and 'ethnicity'.

\section{Germany: 'migration background' as a latecomer nation's pragmatic approach?}

Germany, the "undeclared immigration country" (Thränhardt 1992), had long been characterized simultaneously by large-scale immigration and political denial of this fact. ${ }^{14}$ Only in 2005 did Germany introduce a migration-specific category to its population statistics, and henceforth 'persons with a migration background' are being counted. ${ }^{15}$

In Europe, Germany is not an outlier for refraining from the usage of explicitly ethnic categories in population statistics. According to Simon's $(2012,1376)$ review, "19 countries out of 41 do not collect data on ethnicity and thus rely on citizenship and place of birth for defining the ethnic diversity of their population. Among them, however, six countries add information on the place of birth of parents, most of them being in northern Europe."

To understand how this turning point in the politics of belonging could have taken place, one needs to take into account the dynamic negotiations of identity that accompanied the federal republic throughout its existence. Since the end of the Second World War, different groups of 'newcomers' have unwillingly replaced each other in taking on the role of 'the other' in public and political debate, and thus constituted the reference point for the German 'us'. Often, these groups have even been spatially congregated in the same places, seeing as:

there were barracks in many cities, towns and villages which were successively used by, for example, crews from the Reich Labour Service (Reichsarbeitsdienst), then during the war 'foreign employees' (Fremdarbeiter), later DPs (displaced persons [mainly former forced labourers from Eastern Europe]) and finally German expellees (Vertriebene). They

\footnotetext{
14 The following analysis with respect to Germany is primarily based on SVR $(2015,144-147)$.

15 The Federal Statistical Office $(2014,4)$ defines people with a migration background as all foreigners and naturalised former foreigners, all people who migrated to the present territory of the Federal Republic of Germany as Germans after 1949 as well as all people born as Germans in Germany who have at least one parent who has either migrated to Germany or was born in Germany as a foreign citizen.
} 
also not infrequently found use as 'guest worker barracks' (Gastarbeiterlager) in the early 1960s (Herbert 2003, 197, own translation).

The terms that were used in the political and public debate for the various 'others' (subsequently or sometimes in parallel) included: 'foreign workers', 'guest workers', 'foreigners', 'Turks', 'Asylanten' (a pejorative term used to refer to asylum seekers), 'foreign co-citizens', 'immigrants', 'to-migrants', 'Muslims' and - most recently - 'poverty migrants'.

The national myth of Germany revolves around the community of descent, the "ethnic nation" (Bauder 2014). Contrasting the labels used for non-German migrants with those ascribed to conationals (ethnic German immigrants and expellees ${ }^{16}$ ) illustrates that before the 1990s, the boundaries of German politics of belonging lay between members of the German Volk (Volkszugehörige) and foreigners. The Federal Act on Refugees and Expellees (Bundesvertriebenengesetz) defines belonging to the German 'Volk' as follows: "a member of the German nation according to this Act is somebody who has declared his/her belonging to the German culture, provided that this declaration is confirmed by certain characteristics such as descent, language, education or culture."17

It has been argued that with reunification, a large troublesome part of the German nation-state building process can be deemed mended. Nation-building itself is an ever ongoing process which can never be fully complete. It is in the context of these new circumstances that the country could ultimately start to acknowledge the fact that it had long become a country of immigration (Joppke 1998; see also Hailbronner 1983). Arguably this acceptance constituted a necessary prerequisite for the acknowledgement that measuring population diversity in the census was a necessary and reasonable thing to do. Another factor contributing to the turning point in the politics of belonging was EU legislation. In Europe, the collection of migration-related or 'ethnic' statistics was discussed at the start of the new millennium following the passing of two EU directives on anti-discrimination in 2000 (Simon 2012). Germany, which previously had only distinguished between citizens and non-citizens in its statistics, introduced the new category 'person with a migration background' in the 2004 Microcensus Act, which came into force in 2005. The aim was to statistically track the extent to which certain immigrant groups are integrating into society and continue to suffer from socioeconomic inequality (Pries 2013). One of the results of this new measurement is that German co-ethnics and naturalised foreigners are thus registered alongside foreign nationals as persons with migration background in official statistics; making the dichotomy of 'us' versus 'them' that had been prevalent in the country for decades fragile and porous. However, even with the introduction of this new category, Germany did not move from the second strategy of deriving (family) migration status from citizenship and place of birth (of one's parents) to the strategy of e.g. Canada of explicitly collecting 'ethnic

\footnotetext{
${ }^{16}$ Expellees are persons with German citizenship who were forced to leave former German territory in the East during or in the immediate aftermath of the Second World War or in later waves of expulsion before 1990.

${ }^{17}$ Art. 116 of the German Basic Law defines who is considered to be 'German': “(1) Unless otherwise provided by a law, a German within the meaning of this Basic Law is a person who possesses German citizenship or who has been admitted to the territory of the German Reich within the boundaries of December 31, 1937 as a refugee or expellee of German ethnic origin or as the spouse or descendant of such person. (2) Former German citizens who between January 30, 1933 and May 8, 1945 were deprived of their citizenship on political, racial, or religious grounds, and their descendants, shall on application have their citizenship restored. They shall be deemed never to have been deprived of their citizenship if they have established their domicile in Germany after May 8, 1945 and have not expressed a contrary intention."
} 
data'. Moreover, as in Canada, in Germany the term 'migration background' is applied by the authorities top-down - households that were sampled to participate in the 2011 census were visited by interviewers; the questionnaire is not being filled in by the respondents themselves.

Table 2: Mapping (family) migration history in the German census, 1950-2011

\begin{tabular}{|c|c|c|}
\hline Census year & Concept & Mode \\
\hline 1950 & 'foreigner' & Top-down, citizenship \\
\hline 1956 & 'foreigner' & Top-down, citizenship \\
\hline 1961 & 'foreigner' & Top-down, citizenship \\
\hline 1970 & 'foreigner' & Top-down, citizenship \\
\hline 1987 & 'foreigner' & Top-down, citizenship \\
\hline 2001 & 'foreigner' & Top-down, citizenship \\
\hline 2011 & 'migration background' & $\begin{array}{l}\text { Top-down, through various questions } \\
\text { on place of birth, citizenship, } \\
\text { parents place of birth and } \\
\text { citizenship }\end{array}$ \\
\hline
\end{tabular}

Source: own compilation and design

This top-down ascription is precisely the reason why the introduction and usage of the term 'migration background' had been and continues to be contentious in Germany. While it is indisputably an innovation compared to the previous approach of only distinguishing by citizenship, the term ascribes a heterogeneous group of people a common identity (see among others: Foroutan 2013; Mecheril 2013; Elrick and Schwartzman 2015). In contrast to Canada, where the method of self-identification partially prevents complaints of this sort, this top-down labelling can come with a price. ${ }^{18}$ The term, which was intended to serve a neutral registration of migrants, has arguably taken on a meaning of its own and has lost its intended neutrality in the public and media discourse. As Scarvaglieri and Zech (2013) have shown in a linguistic analysis, the term has increasingly acquired a negative connotation in the public discourse, where it is frequently used to describe a group of people who present an array of different problems and allegedly lack many of the qualities necessary to find a foothold in modern-day society. Similarly, as Elrick and Schwartzman $(2015,1)$ have shown in an analysis of Bundestagsdocuments, state actors tend to "transform this nuanced statistical category into a homogenized social category."

\footnotetext{
${ }^{18}$ Self-identification does, however, carry another set of problems (cf. Jacobs et al. 2009). Moreover, note that some level of top-down ascription is being practiced in Canada (see section above).
} 


\section{Conclusion: statistical mapping of diversity in Canada and Germany - convergence towards a new pragmatism?}

The finding that " $[\mathrm{t}]$ he categories used for newcomers mainly tell us something about the society in which they arrived" (Pries 2013, 55) applies to both countries. From the above comparison the conclusion can be drawn that what the two have in common - large differences notwithstanding - is a new pragmatism in the strategy to measure diversity in population statistics. Canada moved away from making top-down decisions about the categories allowed to be chosen and adapted the census question on the elusive concept of 'ethnic group' according to the changing preferences of its population and introduced the category of 'visible minority' to track the success of non-discrimination policies - especially the latter measure showing a pragmatic motivation to support social cohesion. Germany had long denied being a country of immigration regardless of the fact that it did host relatively large numbers of immigrants. This was arguably ideologically driven in support of its uneasy process of nation-building as a divided country. Having overcome this status of an incomplete nation-state, the country now embraces the demographic fact of immigration also in the form of statistical mapping of its population. The extent to which the statistical mapping of the population in relation to 'origin' or 'identity' is ideologically driven therefore seems to have diminished in both countries.

Census politics constitute an important part of the politics of belonging. The primary explanatory variable for the very different paths observed in census politics seems to be the history of nationbuilding. This variable can be further broken down into a collective founding myth, the historical experiences of diversification, and politics of immigration and ethnicity. In our 'most-extreme' case study, there is the 'settler state' Canada on the one side versus the 'ethnic nation' Germany on the other side of the Atlantic. To understand the Canadian approach of mapping diversity in statistics, it has proved fruitful to take into account the struggles with French-Canadian identityclaims on the one hand and the continuous marginalization of Indigenous peoples on the other hand. The emphasis on people's 'roots' in Canada is in accordance with the imagined nation as a multicultural, multinational settler state. The move towards 'racial' self-identification through the introduction of a 'visible minority' question in 1996 showed the continued desire of the Canadian state to distinguish various ethnic or 'origin' groups in its population. It also signalled a pragmatic progression from earlier more pronounced 'top-down' ascription activities based on the 'origins' question alone. It was also simply the pragmatic way to be able to track social inequalities based on phenotype and origin-based discrimination, due to the changed response behaviour on the 'origins' question.

In post-war Germany, in contrast, the impossibility of measuring 'ethnicity' and struggles over belonging in the 'undeclared country of immigration' are key variables in explaining the country's refrain from measuring 'ethnic' differences and the relatively recent introduction of the intended neutral statistical category, 'migration background'. That the introduction of this category was prompted to an extent by discussions at the EU level, following the introduction of two EU directives on anti-discrimination in 2000, points to another factor that seems to play a role in countries' politics of belonging through census politics: shifting international norms. These seem to have had an even more pronounced effect in Canada (Thompson 2012).

Both the introduction of the 'visible minority' category in Canada and the introduction of the 'migration background' in Germany can be considered a pragmatic and instrumental approach to mapping diversity. The aim of this is to track the effects of (economic) integration measures (cf. 
Joppke 2007) and counteract discrimination and inequalities in an ever more diverse society while complying with shifting international and national norms concerning the selfunderstanding of each country as a country of immigration. Both terms are pragmatic in the sense that they were introduced with the objective of guaranteeing the same opportunities to participate in society. The traditional aim of census politics - preserving a national founding myth - took a backseat. In this limited sense, a convergence of Canadian and German politics of belonging as visible in census politics can be seen, although the differences especially regarding the underlying concept of difference remain significant. Future research should look into the puzzle why France can hardly be said to converge towards this new pragmatism in census politics as well. Generally speaking, it can be strenuous at times that politics of belonging and the boundaries within societies marked by diversity are continuously debated or even heatedly discussed in the public realm. Yet this is undoubtedly a necessary and healthy process in the quest for social cohesion in countries of immigration. 


\section{REFERENCES}

Adamson, Fiona B., Triadafilos Triadafilopoulos, and Aristide R. Zolberg. 2011. "The Limits of the Liberal State: Migration, Identity and Belonging in Europe." Journal of Ethnic and Migration Studies 37: 843-859.

Anderson, Benedict. 1991. Imagined Communities: Reflections on the Origin and Spread of Nationalism. 2nd edition. London/New York: Verso.

Bauder, Harald. 2014. "Re-Imagining the Nation. Lessons from the Debates of Immigration in a Settler Society and an Ethnic Nation." Comparative Migration Studies 2: 9-27.

Bertossi, Christophe. 2012. "The Performativity of Colour Blindness: Race Politics and Immigrant Integration in France, 1980-2012" Patterns of Prejudice 46: 427-444.

Bloemraad, Irene. 2013. "The promise and pitfalls of comparative research design in the study of migration." Migration Studies, 1: 27-46.

Brubaker, Rogers. 2010. "Migration, Membership, and the Modern Nation State: Internal and External Dimensions of the Politics of Belonging." Journal of Interdisciplinary History 41: 61-78.

Crowley, John. 1999. "The Politics of Belonging: Some Theoretical Considerations." In The Politics of Belonging: Migrants and Minorities in Contemporary Europe, edited by Andrew Geddes, and Adrian Favell, 15-41. Aldershot: Ashgate.

Düvell, Franck. 2008. "Clandestine migration in Europe.” Social Science Information 47: 479-497.

Engler, Marcus 2012. "Frankreich: Nachfahren von Migranten weiter benachteiligt." Migration und Bevölkerung 9: 6-7.

Elrick, Jennifer, and Luisa Farah Schwartzman. 2015. "From statistical category to social category: organized politics and official categorizations of ,persons with a migration background' in Germany." Ethnic and Racial Studies 38: 1539-1556. Accessed December 29, 2015. doi: 10.1080/01419870.2014.996240. Federal Statistics Office. 2014. Bevölkerung und Erwerbstätigkeit. Bevölkerung mit Migrationshintergrund. Ergebnisse des Mikrozensus 2013. Fachserie 1 Reihe 2.2. Wiesbaden: Statistisches Bundesamt.

Foroutan, Naika. 2013. "Hybride Identitäten - Normalisierung, Konfliktfaktor und Ressource in postmigrantischen Gesellschaften." In Dabeisein und Dazugehören - Integration in Deutschland, edited by Heinz-Ulrich Brinkmann, and Haci-Halil Uslucan, 85-99. Wiesbaden: Springer VS.

Hailbronner, Kay. 1983: “Ausländerrecht und Verfassung.“ Neue Juristische Wochenschrift, 36: 21052113.

Hamel, Marc, and Yves Béland. 2013. "Future developments on the Canadian Census of Population." Conference Paper presented at the 59th ISI World Statistics Congress, Hong Kong, August 27.

Herbert, Ulrich. 2003. Geschichte der Ausländerpolitik in Deutschland. Saisonarbeiter - Zwangsarbeiter - Gastarbeiter - Flüchtlinge. München: Bundeszentrale für politische Bildung.

Jacobs, Dirk, Marc Swyngedouw, Laurie Hanquinet, Véronique Vandezande, Roger Andersson, Ana Paula Beja Horta, Maria Berger, Mario Diani, Amparo Gonzalez Ferrer, Marco Giugni, Miruna Morariu, Katia Pilati, and Paul Statham. 2009. "The Challenge of Measuring Immigrant Origin and Immigration-related Ethnicity in Europe.“ International Migration \& Integration 10: 67-88.

Joppke, Christian. 1998. Challenge to the Nation-State. Oxford: Oxford University Press. - 2005. Selecting by Origin. Ethnic Migration in the Liberal State. Cambridge: Harvard University Press. 
—. 2007. "Beyond National Models: Civic Integration Policies for Immigrants in Western Europe." West European Politics, 30: 1-22.

Kolb, Holger. 2014. "When Extremes Converge - German and Canadian Labor Migration Policy Compared." Comparative Migration Studies 2: 57-67.

Kymlicka, Will. 1995. Multicultural Citizenship: A Liberal Theory of Minority Rights. Oxford: Oxford University Press.

Leroux, Darryl. 2015. “'A genealogist's paradise': France, Québec and the genealogics of race.” Ethnic and Racial Studies 38: 718-733.

Mecheril, Paul. 2013. "Von der interkulturellen zur migrationsgesellschaftlichen Öffnung rassismuskritische Perspektiven." Paper presented at the Symposium des pädagogischen Instituts in München, Munich.

Pries, Ludger. 2013. "Changing Categories and the Bumpy Road to Recognition in Germany." In Shifting Boundaries of Belonging and New Migration Dynamics in Europe and China, edited by Ludger Pries, 55-85. Houndmills: Palgrave Macmillan.

Scarvaglieri, Claudio, and Claudia Zech. 2013. ""Ganz normale Jugendliche, allerdings meist mit Migrationshintergrund". Eine funktional-semantische Analyse von "Migrationshintergrund"." Zeitschrift für Angewandte Linguistik 58: 201-227.

Schnapper, Dominique. 1994. La Communauté des Citoyens. Sur l'Idée Moderne de Nation, Paris: Gallimard.

Seltzer, William. 1998. "Population Statistics, the Holocaust, and the Nuremberg Trials." Population and Development Review 24: 511-552.

Simon, Patrick. 2012. "Collecting Ethnic Statistics in Europe: A Review.” Ethnic and Racial Studies, 35: 1366-1391.

Soennecken, Dagmar. 2014. "Shifting Up and Back - The European Turn in Canadian Refugee Policy." Comparative Migration Studies 2: 101-122.

Statistics Canada. 2013. Immigration and Ethnocultural Diversity in Canada - National Household Survey, 2011, Ottawa.

Stevens, Gillian, Hiromi Ishizawa, and Douglas Grbic. 2015. "Measuring race and ethnicity in the censuses of Australia, Canada, and the United States: Parallels and paradoxes." Canadian Studies in Population 42: 13-34.

SVR. 2015. Unter Einwanderungsländern: Deutschland im internationalen Vergleich. Jahresgutachten 2015, Berlin: SVR.

Thompson, Debra. 2012. "Making (mixed-)race: census politics and the emergence of multiracial multiculturalism in the United States, Great Britain and Canada." Ethnic and Racial Studies 35: $1409-1426$.

Thränhardt, Dietrich. 1992. Europe - A New Immigration Continent. Policies and Politics in Comparative Perspective, Münster/Hamburg/Boulder: LIT Verlag.

Triadafilopoulos, Triadafilos. 2012. Becoming multicultural - Immigration and the politics of membership in Canada and Germany, Vancouver: UBC Press.

Valente, Paolo. 2010. "Census taking in Europe: how are populations counted in 2010?" Population \& Societies 467: 1-4. 
von Bogdandy, Armin, Stefan Häußler, Felix Hanschmann, and Raphael Utz. 2005. "State-Building, Nation-Building, and Constitutional Politics in Post-Conflict Situations: Conceptual Clarifications and an Appraisal of Different Approaches." In Max Planck Yearbook of United Nations Law, Volume 9, edited by von Bogdandy, Armin, and R. Wolfrum, 579-613. Leiden/Boston: Martinus Nijhoff Publishers.

Wihtol de Wenden, Catherine, Monika Salzbrunn, and Serge Weber. 2013. "Beyond Assimilation: Shifting Boundaries of Belonging in France." In Shifting Boundaries of Belonging and New Migration Dynamics in Europe and China, edited by Ludger Pries, 26-54. Houndmills: Palgrave Macmillan.

Winter, Elke. 2014. Us, Them, and Others: Reflections on Canadian Multiculturalism and National Identity at the Turn of the Twenty-First Century, John Porter Lecture at the Canadian Sociological Association, Victoria, 04/06/2013.

- 2015. Rethinking Multiculturalism After its "Retreat": Lessons From Canada, in: American Behavioral Scientist, published online 12/01/2015.

Zhang, Li. 2001. Strangers in the City: Reconfigurations of Space, Power and Social Networks Within China's Floating Population, Stanford: Stanford University Press.

Zolberg, Aristide Z. 1999. "Matters of State: Theorizing Immigration Policy." In The Handbook of International Migration: The American Experience, edited by Charles Hirschman, Philip Kasinitz, and Josh DeWind, 71-93. New York: Russell Sage Foundation. 
Published by the Centre for European Studies at Carleton University, Ottawa, Canada Available online at: journals.carleton.ca/rera/index.php/rera

RERA is an electronic academic peer-reviewed journal. Topics relate to the European Union, its Member States, the former Soviet Union, and Central and Eastern Europe. The journal is a joint project supported by the Canada-Europe Transatlantic Dialogue - a cross-Canada research network supported by the Social Sciences and Humanities Research Council of Canada (SSHRC) - along with the Institute of European, Russian and Eurasian Studies (Carleton University) and its associated research unit, the Centre for European Studies.

RERA aims to provide an accessible forum for research, to promote high standards of research and scholarship, and to foster communication among young scholars.

\section{Contact:}

Carleton University

The Centre for European Studies

1103 Dunton Tower

1125 Colonel By Drive

Ottawa, ON K1S 5B6

Canada

Tel: +01 613 520-2600 ext. 3117; E-mail: rera-journal@ carleton.ca

\section{Creative Commons License}

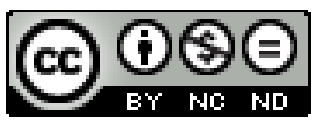

creativecommons.org/licenses/by-nc-nd/3.0

This Working Paper is licensed under a Creative Commons Attribution-Non-CommercialNo Derivs 3.0 Unported License (CC BY-NC-ND 3.0).

Articles appearing in this publication may be freely quoted and reproduced, provided the source is acknowledged. No use of this publication may be made for resale or other commercial purposes.

ISSN: 1718-4835

(C) 2017 The Author(s) 